\title{
Enkephalins Increase Cyclic Adenosine Monophosphate Content, Calcium Uptake, and Contractile State in Cultured Chick Embryo Heart Cells
}

Stephane Laurent, James D. Marsh, and Thomas W. Smith

Cardiovascular Division, Department of Medicine, Brigham \& Women's Hospital and

Harvard Medical School, Boston, Massachusetts 02115

\begin{abstract}
Peripheral vascular effects of opioid peptides are well known, but direct myocardial effects have not been established. We studied the inotropic response of spontaneously beating cultured chick embryo ventricular cells to the enkephalin analogue [DAla ${ }^{2}$-enkephalin. Amplitude of cell motion increased in a concentration-dependent manner with $0.53 \mu \mathrm{M}\left[\mathrm{D}-\mathrm{Ala}{ }^{2}\right]$-enkephalin producing half-maximal response. The mechanism of this positive inotropic effect was investigated by examining alterations in ${ }^{45} \mathrm{Ca}$ influx, cyclic AMP accumulation and adenylate cyclase activity in response to $\left[\mathrm{D}-\mathrm{Ala}{ }^{2}\right]$-enkephalin. At maximally inotropic concentrations, the ${ }^{45} \mathrm{Ca}$ influx rate increased $39 \%$, adenylate cyclase was stimulated by $30 \%$, and cyclic AMP content rose more than twofold. Thus, in contrast to neural tissue, receptors for enkephalin in cultured heart cells are coupled to adenylate cyclase in a stimulatory manner. Occupancy of these receptors produces an increase in cyclic AMP levels and exerts a positive inotropic effect via a verapamil-sensitive enhancement of $\mathrm{Ca}$ influx.
\end{abstract}

\section{Introduction}

In most receptor-effector systems, opiates and opiate peptides have an inhibitory effect (1-4), although some exceptions have been observed (5). Opiates have been demonstrated both to blunt the physiological response to sympathetic stimulation (4) and to inhibit directly adenylate cyclase activity in the absence of $\beta$ adrenergic stimulation (2). Interaction of opiates with neurotransmitters regulating cardiac performance was suggested by the early study of Kosterlitz and Taylor (6), demonstrating that morphine reduced cardiac slowing produced by vagal stimulation. Subsequently, a number of studies reported that enkephalins and opiates have direct or modulatory effects on the heart $(3,4,7-9)$.

Recent studies from our laboratory on the native opioid peptides Met-enkephalin and Leu-enkephalin, as well as the stable synthetic enkephalin analogues (D-Ala ${ }^{2}$ ) Met-enkephalin $(D A L A)^{1}$ and (D-Ala ${ }^{2}$, D-Leu ${ }^{5}$ ) Leu-enkephalin (DADLE), dem-

Address all correspondence to Dr. Marsh, Brigham and Women's Hospital, 75 Francis Street, Boston, MA 02115.

Received for publication 25 November 1985

1. Abbreviations used in this paper: DALA, (D-Ala $\left.{ }^{2}\right)$ Met-enkephalin; DADLE, (D-Ala ${ }^{2}, \mathrm{D}-\mathrm{Leu}^{5}$ ) Leu-enkephalin; $\mathrm{EC}_{50}$, effective concentration $_{\text {so }} ; \mathrm{FCS}$, fetal calf serum; $\mathrm{G}_{\mathrm{i}}$, inhibitory guanine nucleotide regulatory subunit; $\mathrm{G}_{\mathbf{3}}$, stimulatory guanine nucleotide regulatory subunit; IBMX, isobutyl methylxanthine.

J. Clin. Invest.

(c) The American Society for Clinical Investigation, Inc.

0021-9738/86/05/1436/05 $\$ 1.00$

Volume 77, May 1986, 1436-1440 onstrated that these compounds increased the contractility of cultured chick myocytes (a noninnervated preparation) in a concentration- and time-dependent manner. The positive inotropic effect of these compounds was antagonized by the opiate antagonist naloxone but not by $\beta$-adrenergic, $\alpha$-adrenergic, $H_{1}$, or $\mathrm{H}_{2}$ antagonists (10). Specific opiate receptors were characterized by ligand binding techniques in cell membranes. These initial observations led us to probe the cellular mechanism of the positive inotropic effect of enkephalins.

In most cardiac systems, opiates and enkephalins appear to have a negative modulatory effect. In neural tissue, receptors for enkephalins have been demonstrated to be coupled to adenylate cyclase in an inhibitory fashion. We now report quite different, direct effects on noninnervated cultured cardiac myocytes. We find that occupancy of enkephalinergic receptors stimulates adenylate cyclase and exerts a positive inotropic effect by augmenting $\mathrm{Ca}^{++}$influx through the slow $\mathrm{Ca}$ channel.

\section{Methods}

Tissue culture. Monolayer cultures of beating chick embryo ventricular cells were prepared as previously described (11). Briefly, 10-d chick embryo hearts were removed under sterile conditions, and the ventricles were cut into $0.5-\mathrm{mm}$ fragments and placed in $\mathrm{Ca}^{++}$- and $\mathrm{Mg}^{++}$-free Hanks' solution. The ventricular fragments were gently agitated in 10 $\mathrm{ml}$ of $0.025 \%$ (wt/vol) trypsin (Gibco, Grand Island, NY), and $\mathrm{Ca}^{++}$. and $\mathbf{M g}^{++}$-free Hanks' solution at $37^{\circ} \mathrm{C}$ for four or five cycles of $7 \mathrm{~min}$ each. The supernatant suspensions of dissociated cells were placed in 20 $\mathrm{ml}$ of cold trypsin inhibitor medium containing $50 \%$ heat-inactivated fetal calf serum (FCS) and $50 \% \mathrm{Ca}^{++}$- and $\mathbf{M g}^{++}$-free Hanks' solution. The suspension was centrifuged at $150 \mathrm{~g}$ for $10 \mathrm{~min}$, the supernatant was discarded, and the cells were resuspended in culture medium consisting of $6 \%$ heat-inactivated FCS, $40 \%$ M199 (Gibco), 0.1\% penicillinstreptomycin antibiotic solution, and 54\% low potassium salt solution containing (mM) NaCl, 116; $\mathrm{NaH}_{2} \mathrm{PO}_{4}, 1.0 ; \mathrm{MgSO}_{4}, 0.8 ; \mathrm{KCl}, 1.18$; $\mathrm{NaHCO}_{3}, 26.2 ; \mathrm{CaCl}_{2}, 0.87$; and glucose, 5.5. Final concentrations (mM) in the culture medium were: $\mathrm{Na}^{+}, 144 ; \mathrm{K}^{+}, 4.0 ; \mathrm{Ca}^{++}, 0.97 ; \mathrm{HCO}_{3}^{-}, 18$; and $\mathrm{Cl}^{-}, 131$. The suspension of cells was diluted to $5 \times 10^{5}$ cells $/ \mathrm{ml}$ and placed in plastic tissue culture dishes containing 25-mm circular glass coverslips (VWR; thickness \#2). Cells for 3',5'-adenosine monophosphate (cyclic AMP) studies were plated directly on multiwell plates. Cultures were incubated in a humidified $5 \% \mathrm{CO}_{2}-95 \%$ air atmosphere at $37^{\circ} \mathrm{C}$. Confluent monolayers in which at least $70 \%$ of the cells were contracting developed by $2 \mathrm{~d}$ in culture. Studies on contractility and cyclic AMP were done at 3 or $4 \mathrm{~d}$ in culture; control experiments showed no difference in results between day 3 and day 4 . For cultures used in contractility studies, plastic microspheres $2-3 \mu \mathrm{m}$ in diameter (3M Co., St. Paul, MN) were added to the cultures on the second day of growth. The plastic microspheres became attached to the cell surface and moved with contraction of individual cells in the monolayer. This provided an improved image for contraction recording and quantitation.

Measurement of contractility. A glass coverslip with attached heart cell monolayer was placed in a specially designed perfusion chamber that permitted continuous flow of perfusing medium over the monolayer. The chamber was placed on the stage of an inverted phase contrast microscope (Leitz Diavert, Rockleigh, NJ) enclosed in a Lucite box with 
controlled temperature $\left(37^{\circ} \pm 0.5^{\circ} \mathrm{C}\right)$. The inlet to the perfusion chamber was connected by tubing to four syringe pumps allowing perfusion of the monolayer with a variety of prewarmed test media. Flow characteristics of the chamber were estimated by inodcyanine green dye washout. Using a flow rate of $0.96 \mathrm{ml} / \mathrm{min}$, medium bathing a cell on the center of a coverslip was exchanged with a time constant of about $15 \mathrm{~s}$. Media samples from the chamber were analyzed (pH-gas analyzer, Instrumentation Laboratories, Lexington, MA), and consistently found to have a $\mathrm{PO}_{2}>100$ and a pH of 7.3. The optical apparatus was supported by an air table to dampen building vibrations, and the cells were magnified using a $40 \times$ objective. The image was monitored by a low light level silicon TV camera (650 SSX, Dage, Michigan City, IN) attached to the microscope observation tube with a $2 \times$ coupler. The TV camera video output was connected to a video motion detector (Model 633, Colorado Video, Boulder, $\mathrm{CO}$ ) and displayed on a Conrac TV monitor (Conrac; Covina, CA). The total magnification of the image on the monitor screen was $2,000 \times$. The TV camera had an interlace defeat producing an image composed of 262 raster lines. The motion detector monitored a selected raster-line segment and provided new position data every $16 \mathrm{~ms}$ for a microsphere within the monolayer moving along the raster line. The analog voltage output from the motion detector was filtered at $15 \mathrm{~Hz}$ with a $48 \mathrm{db} / o c t a v e$ lowpass active filter and was calibrated to indicate actual $\mu \mathrm{m}$ of motion. The analog tracing was recorded with a strip chart recorder. Rate and amplitude of contraction were recorded periodically. Previous studies (11-14) have demonstrated that changes in amplitude and velocity of wall motion can be used to quantify the effects of a variety of interventions on cell contractility.

Protocol for contractility measurement. Coverslips with spontaneously contracting monolayers were continuously superfused with $0.6 \mathrm{mM} \mathrm{Ca}^{++}$ medium for $10 \mathrm{~min}$ and the amplitude of contraction of a selected cell was continuously recorded. When the response had stabilized, the monolayer was exposed to the test solution. For each cell studied, the inotropic response was expressed as the percentage of the response to $3.6 \mathrm{mM} \mathrm{Ca}^{++}$. This $\mathrm{Ca}^{++}$concentration elicits a maximal inotropic response and helps to normalize results from individual experiments. Loading conditions for contraction caused by attachment of the cell to the coverslip and to other cells, as well as the viscoelastic properties of each cell, may vary from cell to cell. By expressing the contractile response of a given cell as a percentage of its maximal response (11), differences in loading conditions are normalized, and each cell serves as its own control. Previous studies from this laboratory have demonstrated that this method of assessing the inotropic state of cultured cells correlates with other physiological parameters known to relate to the inotropic state, such as alterations in monovalent and divalent cation fluxes (11). Contractility measurements were made on one cell per coverslip. Several coverslips were used from one plating and all experimental points include data from two or more platings.

Synthetic enkephalin analogs DALA and DADLE had effects similar to native Met- and Leu-enkephalin on the contractile state of spontaneously beating cultured heart cells (10). DALA was used in this series of experiments because they are resistant to enzymatic hydrolysis (15, 16). For concentration-effect experiments, each cell was superfused by only one concentration of enkephalin; each point is the mean \pm SEM of data from at least three different preparations.

Ion flux measurements. To determine if the positive inotropic effect of enkephalins could be correlated with calcium influx via the slow calcium channel, we studied ${ }^{45} \mathrm{Ca}^{++}$uptake at the maximally inotropic DALA concentrations in the presence and absence of the calcium channel antagonist verapamil. The method for measuring ${ }^{45} \mathrm{Ca}^{++}$uptake rates was as previously described (11). The rapid phase of calcium exchange was measured by exposing beating cells to medium containing ${ }^{45} \mathrm{Ca}^{++}$ $\left(5 \mu \mathrm{Ci} / \mathrm{ml} ;[\mathrm{Ca}]_{0}=0.6 \mathrm{mM}\right)$ for 10,20 or $30 \mathrm{~s}$. This exposure to ${ }^{45} \mathrm{Ca}^{++}$ labels the rapidly exchangeable calcium pool (12). After appropriate periods of ${ }^{45} \mathrm{Ca}^{++}$uptake in the presence or absence of enkephalins and/ or verapamil, cells were washed twice for $8 \mathrm{~s}$ by gently agitating the glass coverslips in $60 \mathrm{ml}$ of ice-cold Hanks' balanced salt solution without radiolabeled ions. Cells were then dissolved in medium containing $1 \%$ sodium dodecyl sulfate and $10 \mathrm{mM}$ sodium borate and aliquots assayed by liquid scintillation spectrometry (Model 3330, Packard Instrument Co., Downer's Grove, IL). Incubation for $24 \mathrm{~h}$ prior to the experiment in $\mathrm{L}-\left[4,5-{ }^{3} \mathrm{H}(\mathrm{N})\right]$-leucine $(0.1 \mu \mathrm{Ci} / \mathrm{ml})$, determination of the ratio of ${ }^{3} \mathrm{H}$ counts to protein concentration, and simultaneous counting of ${ }^{3} \mathrm{H}$ and ${ }^{45} \mathrm{Ca}^{++}$permitted normalization of calcium uptake data per milligram cell protein on each coverslip.

Adenylate cyclase and cyclic AMP measurements. For measurements of cyclic AMP, the medium for cells grown in multiwell plates was changed to Hepes-buffered Hanks' balanced salt solution at $37^{\circ} \mathrm{C}$. Stimulating drugs were added and cyclic AMP production permitted to proceed for $5 \mathrm{~min}$. The reaction was then terminated by addition of icecold 2\% TCA. Well contents were quantitatively transferred to glass tubes and centrifuged. The pellet was analyzed for protein content by the method of Lowry et al. (17). The supernatant was extracted four times with ether and the aqueous cyclic AMP was acetylated and quantitated by radioimmunoassay (18). The assay was linear from 1 to $20 \mathrm{pmol} /$ tube. All interventions affecting cyclic AMP content were performed in triplicate and radioimmunoassays for each well were performed in triplicate.

To permit direct comparison of contractile measurements, cyclic AMP measurements and ${ }^{45} \mathrm{Ca}^{++}$uptake, all experiments were conducted using identical physiological buffer at $37^{\circ} \mathrm{C}$ on replicate intact cell preparations.

Adenylate cyclase activity was measured in homogenates of cultured cells using a modification of the method of Krishna (19) as previously described $(13,20)$. The maximal inotropic concentration of DALA $(10$ $\mu \mathrm{M})$ was used and $10^{-4} \mathrm{M}$ guanosine triphosphate was present. Assays were performed in triplicate.

Materials. [D-Ala ${ }^{2}$-enkephalin acetate salt, dl-propranolol, l-isoproterenol, isobutyl methylxanthine and guanosine triphosphate were purchased from Sigma Chemical Co., St. Louis, MO. Naloxone was obtained from DuPont Co., Wilmington, DE. Antibody to succinylated cyclic AMP was the gift of Dr. Gary Brooker. Tissue culture supplies were from sources previously described (21).

Statistical analysis. Statistical analysis of cyclic AMP content data was by analysis of variance followed by paired $t$ tests or by rank-sum test if data were nonparametric. Analysis of adenylate cyclase activity was by paired $t$ test followed by Bonferroni correction for multiple comparisons. The significance level of $P=0.05$ was utilized to reject the null hypothesis. Other statistical methods were applied as specifically noted.

\section{Results}

To determine whether the positive inotropic effect of DALA could be related to cyclic AMP production, we first measured cyclic AMP concentrations and contractile responses to graded concentrations of DALA (Fig. 1). DALA increased the amplitude of contraction for cultured myocytes in a monotonic fashion. Log-logit analysis yielded an Effective Concentration ${ }_{50}\left(\mathrm{EC}_{50}\right)$ for the positive inotropic effect of $0.53 \mu \mathrm{M}$. In an identical cultured cell preparation, DALA produced a concentration-dependent increase in cyclic AMP content over a time course and concentration range quite similar to that for the augmentation of contractile state. The $\mathrm{EC}_{50}$ for augmentation of cyclic AMP production was $0.60 \mu \mathrm{M}$ (Fig. 1).

To confirm the specificity of the effect of DALA on cyclic AMP content, we examined its effect on cyclic AMP content after $10 \mu \mathrm{M}$ naloxone. Naloxone by itself was without effect on cyclic AMP content, but it abolished the response to DALA. Furthermore, $1 \mu \mathrm{M}$ propranolol was without effect on DALA stimulation of cyclic AMP content, whereas it abolished the effect of $0.1 \mu \mathrm{M}$ isoproterenol on the same preparation (Table I).

Positive inotropic effects of $\beta$-adrenergic agonists associated with augmented cyclic AMP content of cardiac cells are mediated by stimulation of transsarcolemmal $\mathrm{Ca}^{++}$flux via voltage-dependent Ca channels (22). To determine whether the enkephalin 


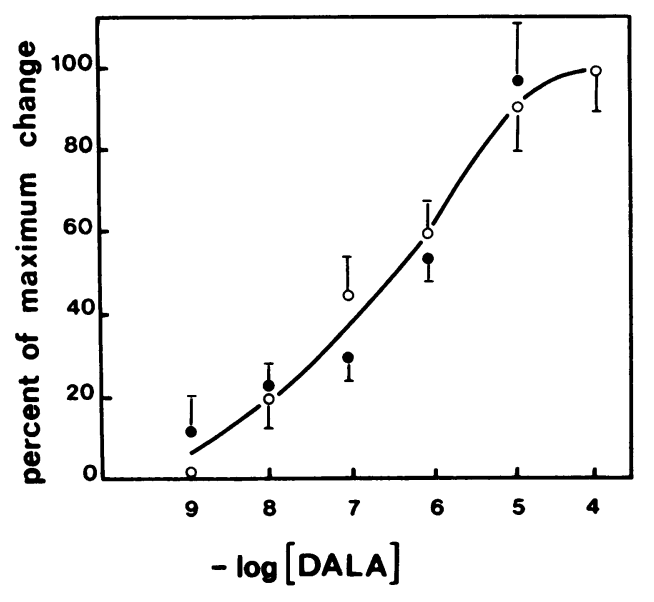

Figure 1. Concentration-effect curve for increase in amplitude of contraction ( $(0)$ and intracellular cyclic AMP content $(\bullet)$ in intact cultured heart cells in response to DALA. Each point is the mean \pm SEM of three experiments. The concentration-effect curve for the positive inotropic effect $\left(\mathrm{EC}_{50}=5.3 \times 10^{-7} \mathrm{M}\right)$ was superimposable on the curve for increased cyclic AMP $\left(\mathrm{EC}_{50}=6 \times 10^{-7} \mathrm{M}\right)$. The threshold concentration for a measureable increase in cyclic AMP was $10 \mathrm{nM}$ DALA.

analogue DALA stimulated $\mathrm{Ca}^{++}$influx in cultured heart cells, we measured ${ }^{45} \mathrm{Ca}^{++}$uptake in response to $10 \mu \mathrm{M}$ DALA, the maximally inotropic concentration, as determined in Fig. 1. DALA markedly increased ${ }^{45} \mathrm{Ca}^{++}$uptake at this concentration, with a significant increase in ${ }^{45} \mathrm{Ca}^{++}$content evident by $10 \mathrm{~s}$ after DALA exposure (Fig. 2). We have shown previously that approximately two-thirds of $\mathrm{Ca}$ uptake in this preparation is dependent on the $\mathrm{Na}$ gradient and hence is thought to occur via

Table I. Cyclic AMP and Adenylate Cyclase Response

\begin{tabular}{|c|c|c|c|}
\hline Stimulating agent & $\begin{array}{l}\text { Intracellular } \\
\text { cyclic AMP } \\
\text { concentration }\end{array}$ & $\begin{array}{l}\text { Adenylate } \\
\text { cyclaseł } \\
\text { activity }\end{array}$ & $\begin{array}{l}\text { Fold } \\
\text { stimulation }\end{array}$ \\
\hline & $\begin{array}{l}\text { pmol cAMP/mg } \\
\text { protein }\end{array}$ & $\begin{array}{l}\text { pmol } \mathrm{cAMP} / \mathrm{mg} \\
\text { protein per } 10 \mathrm{~min}\end{array}$ & \\
\hline Basal & $7.2 \pm 0.7$ & $1,455 \pm 72$ & \\
\hline DALA $(10 \mu \mathrm{M})$ & $16.1 \pm 2.6^{\prime \prime}$ & $2,386 \pm 329 \S$ & 1.63 \\
\hline Naloxone $(0.1 \mu \mathrm{M})$ & $8.2 \pm 0.5$ & & \\
\hline \multicolumn{4}{|l|}{ Naloxone $(0.1 \mu \mathrm{M})$} \\
\hline + DALA $(10 \mu \mathrm{M})$ & $8.8 \pm 0.4$ & & \\
\hline Isoproterenol $(0.1 \mu \mathrm{M})$ & $28.3 \pm 4.5^{\prime \prime}$ & & \\
\hline Isoproterenol $(1 \mu \mathrm{M})$ & & $2,731 \pm 562 \S$ & 1.87 \\
\hline Propranolol $(1 \mu \mathrm{M})$ & $7.8 \pm 4.5$ & & \\
\hline \multicolumn{4}{|l|}{ Propranolol (1 $\mu \mathrm{M})$} \\
\hline+ isoproterenol $(1.0 \mu \mathrm{M})$ & $8.5 \pm 0.6$ & & \\
\hline \multicolumn{4}{|l|}{ Propranolol $(1 \mu \mathrm{M})$} \\
\hline + DALA $(10 \mu \mathrm{M})$ & $14.4 \pm 1.3 \S$ & & \\
\hline Basal + IBMX (0.1 mM) & & $1,687 \pm 62$ & \\
\hline \multicolumn{4}{|l|}{ DALA $(10 \mu \mathrm{M})+$ IBMX } \\
\hline$(0.1 \mathrm{mM})$ & & $2,755 \pm 141 \S$ & 1.63 \\
\hline
\end{tabular}

* Naloxone antagonism of DALA-induced increase in cyclic AMP. Intact cells were preincubated with antagonists naloxone or propranolol for $10 \mathrm{~min}$ before adding DALA or isoproterenol. Each point is the mean \pm SEM of three experiments.

₹ Stimulation of adenylate cyclase activity by DALA at maximally inotropic concentration.

$\S P<0.05$ compared to control.

" $P<0.01$ compared to control.

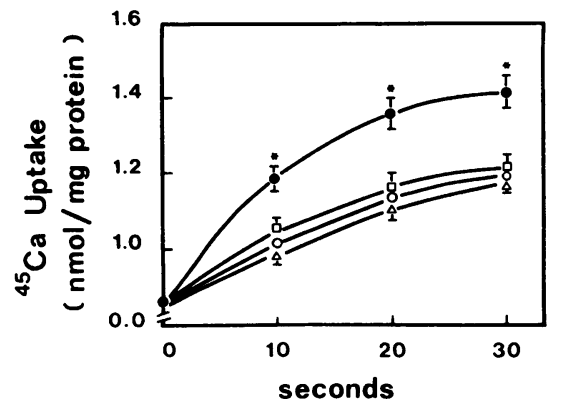

Figure $2 .{ }^{45} \mathrm{Ca}$ uptake by spontaneously beating cultured heart cells under control conditions ( $\square$ ); in response to $1 \times 10^{-5} \mathrm{M}$ (DALA) (๑); $1 \times 10^{-6} \mathrm{M}$ verapamil $(\Delta)$; or $1 \times 10^{-6} \mathrm{M}$ verapamil $+1 \times 10^{-5} \mathrm{M}$ DALA (o). These curves are representative of three replicate experiments. Statistical analysis was performed by analysis of variance followed by Student's $t$ test for unpaired data. Each point is the mean \pm SEM of seven determinations. ${ }^{*} P<0.05$ compared to control values.

$\mathrm{Na}-\mathrm{Ca}$ exchange. The remaining one-third can be blocked by $\mathrm{Ca}$ channel blockers such as verapamil or nifedipine $(11,12)$. We examined the effect of $1 \mu \mathrm{M}$ verapamil on DALA-stimulated $\mathrm{Ca}^{++}$uptake. Verapamil abolished the effect of DALA on $\mathrm{Ca}$ uptake, indicating that most of DALA's effect was on Ca channeldependent $\mathrm{Ca}$ flux (Fig. 2).

To examine the point in the pathway at which cyclic AMP levels are affected by enkephalins, we determined the effect of the phosphodiesterase inhibitor isobutyl methylxanthine (IBMX) on the contractile response to DALA. IBMX by itself increased the contractile state of the cultured heart cells in a time- and concentration-dependent manner. When cells were exposed to a threshold concentration of DALA $\left(1 \times 10^{-8} \mathrm{M}\right)$, contractility increased by $5 \pm 2 \%$. If cells were first exposed to $1 \mu \mathrm{M}$ IBMX, then $1 \times 10^{-8} \mathrm{M}$ DALA, then contractile response was $14 \pm 2 \%$ $(n=4)$. Thus the phosphodiesterase inhibitor markedly augmented the contractile response to an enkephalin. This finding is consistent with the view that there is a causal relationship between augmentation of cyclic AMP content and the positive inotropic effect observed.

As a second approach to determining whether enkephalins stimulate adenylate cyclase or augment cyclic AMP content by inhibiting its hydrolysis, we measured adenylate cyclase activity in cultured cell homogenates. $10 \mu \mathrm{M}$ DALA stimulated adenylate cyclase activity 1.63 -fold, a response nearly as great as the response to $1 \mu \mathrm{M}$ isoproterenol in the same preparation (Table I). IBMX at $100 \mu \mathrm{M}$ did not alter the stimulation of adenylate cyclase activity by DALA. Taken together, these observations support the hypothesis that enkephalins stimulate adenylate cyclase. While it is not necessary to postulate a second, independent effect of enkephalins on phosphodiesterase activity, such an effect cannot be excluded by the present data.

\section{Discussion}

There are several mechanisms by which a positively inotropic agent might exert its effect. These include elevated $\left[\mathrm{Na}^{+}\right]_{\mathrm{i}}$ leading to increased $\left[\mathrm{Ca}^{++}\right]_{i}$ via $\mathrm{Na}-\mathrm{Ca}$ exchange (12); enhanced contractile element sensitivity to $\mathrm{Ca}^{++}$; or elevation of intracellular [cyclic AMP] either by adenylate cyclase stimulation or phosphodiesterase inhibition. The principal observation reported here 
is that the positive inotropic effect of enkephalins on cultured chick embryo myocardial cells is correlated with adenylate cyclase stimulation and consequent increases in cyclic AMP and calcium influx.

The effects of opiates in most experimental settings studied previously are inhibitory $(1,23)$. Enkephalins inhibit the release of acetylcholine from myenteric nerves and inhibit spontaneous contraction in the guinea pig ileum $(24,25)$. Enkephalins have also been reported to inhibit the release of norepinephrine at the neuroeffector junction $(24,26)$. Since enkephalins may be stored in the same granules as catecholamines (27), they are in a position to exert direct postjunctional effects as well.

A number of lines of evidence suggest that enkephalinergic modulation of cardiac performance may occur. Enkephalinergic innervation of the heart has been shown in the guinea pig (27, 28 , and in the rat heart substantial amounts of preproenkephalin-messenger RNA have been found (29).

The cultured heart cell preparation utilized in our studies contains no neural elements and no endogenous neurotransmitters. Therefore it is well suited for examination of direct myocardial effects of enkephalins. In more complex systems such as intact rat atria, which contain endogenous sympathetic and parasympathetic neuroeffectors, enkephalins have been reported to have no net effect on contractility (30). This finding might be attributed to balanced opposing influences, lack of specific opiate receptors, or other factors. The cultured myocardial cell preparation obviates many such problems.

The effect of opiates on $\mathrm{Ca}^{++}$uptake has been studied in several preparations. Extensive evidence indicates that opiates inhibit the uptake of $\mathrm{Ca}^{++}$into nerve terminals (31). In contrast, Leu-enkephalin has been reported to increase norepinephrinestimulated ${ }^{45} \mathrm{Ca}^{++}$uptake (7) in guinea pig atria. In the studies reported here, we show that DALA directly increased ${ }^{45} \mathrm{Ca}^{++}$ uptake into a rapidly exchangeable $\mathrm{Ca}^{++}$pool in intact beating heart cells. While blockade by naloxone was not tested, this increase in $\mathrm{Ca}$ influx is likely mediated by stimulation of adenylate cyclase and cyclic AMP-dependent phosphorylation of a membrane protein or proteins. The ability of DALA to augment cyclic AMP content closely parallels the inotropic response in the same preparation, suggesting that the inotropic response is cyclic AMPmediated. Furthermore, the DALA-induced increase in cyclic AMP was antagonized by naloxone but not by propranolol, supporting a specific enkephalin action at opiate receptors on the chick embryo ventricular cell.

Studies on opiate modulation of adenylate cyclase (which have primarily been conducted in neural tissue) have usually demonstrated an inhibition of adenylate cyclase and a decrease in cyclic AMP (2), although there have been exceptions to this general finding $(32,33)$. One must consider the possibility that the stimulatory effect of enkephalins reported here may simply be due to species or developmental differences of chick embryo heart cells. While such possibilities are difficult to exclude absolutely, a large number of studies from this and other laboratories on the physiological and pharmacological properties of embryonic chick heart cells have yielded results qualitatively similar to those reported for mammalian species $(34,35)$.

At least two types of guanine nucleotide regulatory subunits modulate adenylate cyclase (36): the stimulatory guanine nucleotide regulatory subunit $G_{s}$ and the inhibitory subunit $G_{i}$. The inhibitory opiate effects are presumed to be mediated by $G_{i}$. Some studies on the interaction of opiates with the myocardium are also consistent with adenylate cyclase inhibition through $G_{i}(3,4,9)$. However, some effectors (e.g., catecholamines acting through the alpha, receptor) can either stimulate (37) or inhibit $(38,39)$ adenylate cyclase, depending on experimental conditions and the preparation studied. An additional important factor that may alter an effector's action is the state of innervation of tissue (40). The absence of neural elements in the cultured ventricular cell preparation may be of importance with respect to our finding that opiates stimulate adenylate cyclase. Steinberg et al. (41) recently reported that in cultured rat myocytes devoid of neural elements, the $\alpha_{1}$-adrenergic receptor is coupled to the beating rate response in a stimulatory manner. When the myocytes were cocultured with sympathetic neurons, they acquired $G_{i}$ (as judged by the appearance of pertussis toxin substrate) and $\alpha_{1}$-adrenergic stimulation became coupled to the beating rate response in an inhibitory manner. Hence, the alternative possibility that the stimulatory effect of opiates in the cultured myocardial cell system is related to absence of innervation and/or absence of $G_{i}$ deserves study. Whether opiates might stimulate myocardial contractility in conditions of acquired denervation such as cardiac transplantation is also a question of potential interest.

If the direct effect of enkephalins on the myocardium in vivo is indeed stimulatory, then the resulting physiological response of the intact heart to enkephalins may be a combination of direct excitation and indirect neurally mediated inhibitory effects. The direct effect tends to produce a positive inotropic response and the indirect effect a decrease in contractility through inhibition of norepinephrine release (24).

In summary, the positive inotropic response of cultured heart cells to opioid peptides is associated with, and probably caused by, increased adenylate cyclase activity, increased cyclic AMP content and increased $\mathrm{Ca}$ flux via the slow $\mathrm{Ca}$ channel.

\section{Acknowledgments}

We appreciate the secretarial assistance of Mrs. Susan McHale.

This work was supported in part by Grants HL00691 and HL18003 from the National Institutes of Health. Dr. Marsh is the recipient of a Clinical Investigator Award from the National Institutes of Health. Dr. Laurent was the recipient of a fellowship from Ministere des Relations Exteneures (France) and from the Harvard-Arthur Sacks Foundation.

\section{References}

1. Holaday, J. W., and H. H. Loh. 1981. Neurobiology of beta-endorphin and related peptides. In Hormonal Proteins and Peptides. C. H. Li, editor. Academic Press, New York. 205-291.

2. Collier, H. O., and A. C. Roy. 1974. Morphine-like drugs inhibit the stimulation by $\mathrm{E}$ prostaglandins of cyclic AMP formation by rat brain homogenate. Nature (Lond.). 248:24-27.

3. Caffrey, J. L., J. F. Gaugl, and C. E. Jones. 1985. Local endogenous opiate activity in dog myocardium: receptor blockade with naloxone. Am. J. Physiol. 248:H382-388.

4. Eiden, L. E., and J. A. Ruth. 1982. Enkephalins modulate the responsiveness of rat atria in vitro to norepinephrine. Peptides. 3:475478.

5. Bitar, K. N., and B. M. Makhlouf. 1982. Specific opiate receptors on isolated mammalian gastric smooth muscle cells. Nature (Lond.). 297:72-74.

6. Kosterlitz, H. W., and D. W. Taylor. 1959. The effect of morphine on vagal inhibition of the heart. Br. J. Pharmacol. 14:209-214.

7. Ruth, J. A., J. V. Cuizon, and L. E. Eiden. 1984. Leucine-enke- 
phalin increases norepinephrine-stimulated chronotropy and ${ }^{45} \mathrm{Ca}^{++}$uptake in guinea-pig atria. Neuropeptides. 4:185-191.

8. Holaday, J. W. 1983. Cardiovascular effects of endogenous opiate systems. Annu. Rev. Pharmacol. Toxicol. 23:541-594.

9. Lechner, R. B., N. J. Gurll, and D. G. Reynolds. 1985. Naloxone potentiates the cardiovascular effects of catecholamines in canine hemorrhagic shock. Circ. Shock. 16:347-361.

10. Laurent, S., J. D. Marsh, and T. W. Smith. 1985. Enkephalins have a direct positive inotropic effect on cultured cardiac myocytes. Proc. Natl. Acad. Sci. USA. 82:5930-5934.

11. Biedert, S., W. H. Barry, and T. W. Smith. 1979. Inotropic effects and changes in sodium and calcium contents associated with inhibition of monavalent cation active transport by ouabain in cultured myocardial cells. J. Gen. Physiol. 74:475-494.

12. Barry, W. H., Y. Hasin, and T. W. Smith. 1985. Sodium pump inhibition, enhanced $\mathrm{Ca}$ flux via sodium-calcium exchange, and positive inotropic response in cultured heart cells. Circ. Res. 56:231-241.

13. Marsh, J. D., W. H. Barry, E. J. Neer, R. W. Alexander, and T. W. Smith. 1980. Desensitization of chick embryo ventricle to the physiological and biochemical effects of isoproterenol. Circ. Res. 47: 493-501.

14. Clusin, W. T. 1981. The mechanical activity of chick embryonic myocardial cell aggregate. J. Physiol. (Lond.). 320:149-174.

15. Pert, C. B., D. L. Bowie, B. T. W. Fond, and J. K. Chang. 1976. Synthetic analogues of met-enkephalin which resist enzymatic destriction. In Opiates and Endogenous Opiate Peptides. H. W. Kosterlitz, editor. Elsevier, Nother Holland, Biomedical Press, Amsterdam. 79-84.

16. Kosterlitz, H. W., J. A. Lord, S. J. Paterson, and A. A. Waterfield. 1980. Effects of changes in the structure of enkephalins and of narcotic analgesic drugs on their interactions with mu- and delta-receptors. $\mathrm{Br}$. J. Pharmacol. 68:333-342.

17. Lowry, O. H., N. J. Rosebrough, A. L. Farr, and R. J. Randall. 1951. Protein measurement with the Folin phenol reagent. J. Biol. Chem. 193:265-275.

18. Harper, J. F., and G. Brooker. 1975. Femtomole sensitive radioimmunoassay for cAMP and cGMP after 2'O-acetylation by acetic anhydride. J. Cyclic Nucleotide Res. 1:207-218.

19. Krishna, G., B. Weiss, and B. B. Brodie. 1968. A simple, sensitive method for the assay of adenylate cyclase. J. Pharmacol. Exp. Ther. 163: 379-385.

20. Neer, E. J. 1973. The vasopressin-sensitive adenylate cyclase of the rat medulla. J. Biol. Chem. 248:4775-4781.

21. Marsh, J. D., and T. W. Smith. 1985. Receptors for beta-adrenergic agonists in cultured chick ventricular cells. Mol. Pharmacol. 27:10-18.

22. Reuter, H. 1984. Ion channels in cardiac cell membranes. Annu. Rev. Physiol. 46:473-484.

23. Martin, W. R. 1983. Pharmacology of opioids. Pharmacol. Rev. 35:283-323.

24. Waterfield, A. A., R. W. J. Smokeum, J. Hughes, H. W. Kosterlitz, and G. Henderson. 1977. In vitro pharmacology of the opioid peptides, enkephalins and endorphins. Eur. J. Pharmacol. 43:107-116.

25. Down, J. A., and J. C. Szerb. 1980. Kinetics of morphine-sensitive
${ }^{3} \mathrm{H}$-acetylcholine release from guinea-pig myenteric plexus. Br. J. Pharmacol. 68:47-55.

26. Henderson, G., and R. A. North. 1976. Depression by morphine of excitatory junction potentials in the vas deferens of the mouse. Br. J. Pharmacol. 57:341-346.

27. Lang, R. E., K. Hermann, R. Dietz, W. Gaida, D. Ganten, K. Kraft, and T. Unger. 1983. Evidence for the presence of enkephalins in the heart. Life Sci. 32:399-406.

28. Weiher, E., A. T. McKnight, A. D. Corbett, W. Hartschuh, M. Reinecke, and H. W. Kosterlitz. 1983. Characterization of opioid peptides in guinea-pig heart and skin. Life Sci. 33:711-714.

29. Howells, R. D., D. L. Kilpatrick, R. Bhatt, J. J. Monahan, M. Poonian, and S. Udenfriend. 1984. Molecular cloning and sequence determination of rat preproenkephalin cDNA: a sensitive probe for studying transcriptional changes in rat tissues. Proc. Natl. Acad. Sci. USA. 81: 7651-7655.

30. Saunders, W. S., and J. A. Thornhill. 1985. No inotropic action of enkephalins or enkephalin derivative on electrically stimulated atria isolated from lean and obese rats. Br. J. Pharmacol. 85:513-522.

31. Cardenas, H. L., and D. H. Ross. 1976. Calcium depletion of synaptosomes after morphine treatement. Br. J. Pharmacol. 57:521526.

32. Puri, S. K., J. Cochin, and L. Volicer. 1975. Effect of morphine sulfate on adenylate cyclase and phosphodiesterase activities in rat corpus striatum. Life Sci. 16:759-768.

33. Iwatsubo, L., and D. H. Clouet. 1975. Dopamine-sensitive adenylate cyclase of the caudate nucleus of rats treated with morphine of haloperidol. Biochem. Pharmacol. 24:1499-1503.

34. Sperelakis, N., and A. J. Pappano. 1983. Physiology and pharmacology of developing heart cells. Pharmac. Ther. 22:1-39.

35. Marsh, J. D. 1983. The cultured-heart cell: a useful model for physiological and biochemical investigation. Intl. J. Cardiol. 3:465-468.

36. Rodbell, M. 1980. The role of hormone receptors and GTPregulatory proteins in membrane transduction. Nature (Lond.). 284:1722.

37. Chan, T. M., and J. H. Exton. 1977. Beta-adrenergic-mediated accumulation of adenosine 3 ' 5 ' monophosphate in calcium-depleted hepatocytes. J. Biol. Chem. 252:8645-8651.

38. Sabol, S. L., and M. Nirenberg. 1979. Regulation of adenylate cyclase of neuroblastoma $\times$ glioma hybrid cells by beta-adrenergic receptors. J. Biol. Chem. 254:1913-1920.

39. Jacobs, K. H. 1978. Inhibition of platelet adenylate cyclase by beta-adrenergic agonists. In Molecular Biology and Pharmacology of Cyclic Nucleotides. G. Folco and R. Paoletti, editors. Elsevier, Amsterdam. $1265-1278$.

40. Marvin, W. J., D. L. Atkins, V. L. Chittick, D. D. Lund, and K. Hermsmeyer. 1984. In vitro adrenergic and cholinergic innervation of the developing rat myocyte. Circ. Res. 55:49-58.

41. Steinberg, S. F., E. D. Druggle, J. P. Bilezikian, and R. B. Robinson. 1985. Acquisition by innervated cardiac myocytes of a pertussis toxin-specific regulatory protein linked to the alpha-receptor. Science. 230:186-188. 